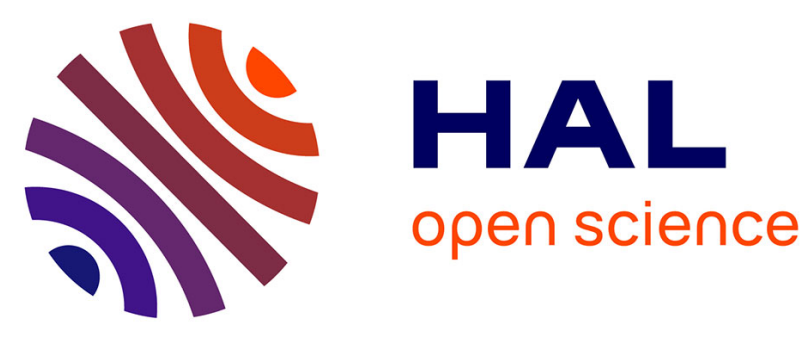

\title{
Role of the UPS pathway in sexual reproduction: Screening for Arabidopsis gametophytic mutations affecting F-box protein genes
}

Sandrine Bonhomme, Monique Durandet, Anouchka Debast Guyon, Alain Lecureuil, Jean-Luc Gallois, Philippe Guerche

\section{To cite this version:}

Sandrine Bonhomme, Monique Durandet, Anouchka Debast Guyon, Alain Lecureuil, Jean-Luc Gallois, et al.. Role of the UPS pathway in sexual reproduction: Screening for Arabidopsis gametophytic mutations affecting F-box protein genes. Annual Main Meeting of the Society for Experimental Biology, Jul 2008, Marseille, France. 10.1016/j.cbpa.2008.04.473 . hal-01203913

\section{HAL Id: hal-01203913 \\ https://hal.science/hal-01203913}

Submitted on 3 Jun 2020

HAL is a multi-disciplinary open access archive for the deposit and dissemination of scientific research documents, whether they are published or not. The documents may come from teaching and research institutions in France or abroad, or from public or private research centers.
L'archive ouverte pluridisciplinaire HAL, est destinée au dépôt et à la diffusion de documents scientifiques de niveau recherche, publiés ou non, émanant des établissements d'enseignement et de recherche français ou étrangers, des laboratoires publics ou privés. 


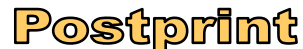

Version définitive du manuscrit publié dans / Final version of the manuscript published in : Comparative Biochemistry and Physiology A Molecular and Integrative Physiology, 150 (3) Supplement 1, DOI:10.1016/j.cbpa.2008.04.473

Role of the UPS pathway in sexual reproduction : Screening for Arabidopsis gametophytic mutations affecting F-box protein genes.

Sandrine Bonhomme, Monique Durandet, Anouchka Guyon-Debast, Alain Lécureuil, JeanLuc Gallois and Philippe Guerche.

INRA UR254, Station de Génétique et d’Amélioration des Plantes, Institut Jean-Pierre Bourgin, Centre de Versailles Grignon, F-78026 Versailles Cedex, France

F-box proteins are central components of the SCF (SKP1-Cullin1-F-box) type of E3Ubiquitin ligases, the enzymes that recognize target proteins, and allow their labelling with ubiquitin chain as a signal for their degradation by the proteasome. Almost 700 F-box protein genes have been reported in the Arabidopsis genome, and several transcriptomic data suggest that half of these F-box protein genes are expressed in the microspore and/or the pollen grain, i.e. the male gametophyte. Aiming at investigating the role of the Ubiquitin Proteasome System (UPS) in plant gametophytes development, we searched for gametophytic insertional mutations affecting genes encoding F-box protein in Arabidopsis. Gametophytic mutants are expected to show a transmission defect of the insertions FST (Flanking Sequence Tags) to the progeny, through either one or both gametophytes. In a first screen, we selected two F-box protein gene candidates, which insertion mutants showed altered transmission through the female gametophyte for one, and either male or female gametophyte for the other. In a second screen, we scored more gene candidates, based on their transcription profile in male gametophyte, by using available microarray data. However, because it has been shown that the expansion of the F-box protein gene family correlates with an increase in gene redundancy among those genes, we expect that gametophytes phenotype could be masked in single mutants. Therefore, we are combining our expression studies with phylogenetic studies in order to generate double and triple mutants for putative redundant F-box protein genes. First candidates will be presented. 